\title{
ASSESSMENT OF SPATIAL PLAN QUALITY BASED ON DISASTER RISK REDUCTION
}

\author{
Rizki Kirana Yuniartanti ${ }^{1^{*}}$ \\ ${ }^{1}$ Lecturer, Esa Unggul University, Kebon Jeruk Campus, Jakarta, Indonesia
}

The island of Bali and its surroundings are part of Indonesia's seismotectonic. This area is traversed by the Mediterranean land line and subduction zone caused by the collision between the Eurasian Plate and the Indo-Australian Plate. Such conditions have been faced by Bali Island as one of the regions that has a high level of seismicity. Hazard potencies in Bali Island especially Karangasem Regency effects disaster prone level. The high level of disaster prone in Karangasem Regency requires disaster preparedness in pre disaster step. Emergency, rehabilitation, and reconstruction responses are not effective responses because these steps need expensive funding and investment. Preparedness efforts in pre-disaster are carried out through enhancement of quality spatial plans based on Disaster Risk Reduction (DRR). Spatial plan contains spatial pattern (land use) plan and development of mitigation infrastructure both of hard infrastructure and soft infrastructure to reduce disaster risk. The research results assessment of quality spatial plans based on hazard potential and DRR in Karangasem Regency using scoring tools. The output is Quality level of Karangasem Spatial Plan that is as a guideline of land use utilization and mitigation infrastructure development. The research can be used other region how to assess spatial plan quality based on disaster risk reduction and also increase the spatial planning quality.

\section{Keywords:}

Disaster, Mitigation, Spatial Planning

\section{Introduction}

Bali Island and its surrounding are a part of Indonesia seismic tectonic. Bali located in Mediterranean mountain path and included subduction zone of Eurasian and Indo Australian Plates. Bali position characteristics cause high seismicity. Based on relief and topography, middle of Bali Island extends outward mountains from west to east and between these mountains there are volcanoes groups (Central Statistics Agency, 2019). The mountains that cause Bali Island is divided two parts; there are northern Bali and South Bali. North Bali is narrower steeper than southern Bali (Suryana, 2012).

Agung mount is one of active and explosive mountains in Indonesia that exceeds Merapi Mount and Sinabung Mount (Geologycal Agency, 2011). The mount that reaches 3.142 meters above sea level erupted in 1808, 1821, 1843, and the last in 1963. Eruption of Agung mount caused 1.148 people death and 296 people injured. Eruption event of Agung Mount occurred in November 2017 after event in 1963. Agung eruption in 2017 resulted volcanic ash that reached 3.500 meters until 4.000 meters. Based on Geological Agency observation, Agung Mount has experienced 21 eruption events and

\section{3 blowing events in 2017.}

Karangasem Regency is a part of Bali Province that has high disaster prone. That is caused Karangasem Regency is a disaster multi prone and Agung Mount located in Karangasem Regency. Karangasem Regency needs Disaster Risk Reduction (DRR) through spatial planning integration.

The Law No. 26 Year 2007 on Spatial Planning and Law No. 24 Year 2007 on Disaster Management mandate to reduce the risk and impact caused by disaster in disaster prone areas through implementation of disaster risk reduction (DRR)-based spatial planning. The paradigms of integrating DRR into Spatial Planning flesh out the disaster management concept. DRR-based spatial planning emphasizes to decrease hazard, reduce vulnerability, and increase capacity. Integrating DRR into spatial planning is a proof of Indonesia's seriousness to carry out Hyogo Framework for Actions (HFA) and Sendai Framework for Disaster Risk Reduction (SFDRR).

Regional Regulation No. 17 Year 2012 on Spatial Plan of Karangasem Regency should be consider DRR-based spatial planning to increase region resilient to face disaster risk. Spatial plan is also as guideline how 
Karangasem Regency to anticipate risk disaster in pre disaster, event disaster, and post disaster that integrates DRR and spatial planning. This research will assess spatial planning of Karangasem Regency based on DRR that can be used as considering Karangasem Regency Government or reduce disaster risk.

\section{Literature Review}

Spatial planning plays a role in long-term spatial use, both in the interaction between land and spatial. Disaster mitigation is included in the components that need to be considered in planning. In planning, response to disaster aspects is focused on disaster mitigation / DRR as a longterm solution compared to emergency response efforts carried out when a disaster occurs. The role of spatial planning that can be achieved in minimizing disaster risk includes long-term risk projections.

On the other hand, spatial planning is also to implement appropriate land use by considering disaster risks. In spatial planning, the infrastructure and activities that are allowed in the KRB have been regulated with a lower risk. Disaster risk elements are also considered in spatial planning (Sutanta, 2012). The purpose of spatial planning based on disaster mitigation / DRR is to achieve regional resilience from disasters (Sutanta, 2012). Spatial planning is a direction in the long term, but can be considered into other spatial planning products in the short and medium term. So that each disaster that has a different return period can be considered in spatial planning based on the spatial planning product arrangement period. The role of spatial planning in disaster mitigation / DRR:

1. Zoning of areas based on disaster risk classification

2. Prohibition and restriction of regional development at high and medium KRB

3. Technical engineering directions in disaster mitigation infrastructure development to reduce disaster risk

The concept of risk sensitive land use planning was introduced by Reyes (2004). This concept is a strategic planning approach that considers hazards, vulnerabilities and capacities in dealing with disasters based on the planning authority.

In making decisions related to spatial planning, the concept of risk sensitive land use planning is combined with disaster risk analysis and spatial planning standards (Reyes, 2004). One of the outputs is alternative spatial utilization based on disaster mitigation / DRR.

Risk sensitive land use planning is oriented to the principle of fairness. This concept will create regions and cities by providing a place to live that is safe, comfortable, and sustainable in the long term.

\section{Research Method}

Spatial Plan assessment considers availability and suitability spatial plan substance based on DRR aspects. Spatial plan substance that will be assessed include:

1. Hazard data

2. Disaster Prone and Risk analysis

3. Goal, policies, and strategies
4. Spatial structure plan

5. Spatial pattern plan

6. Direction of spatial utilization consider disaster prone

7. Zoning Regulation

The following is classification score to assess spatial plan substance:

Table 1. Classification Score to Assess Spatial Plan Substance

\begin{tabular}{|c|c|c|c|c|c|}
\hline \multirow[t]{2}{*}{$\begin{array}{c}\text { Sco- } \\
\text { re }\end{array}$} & \multicolumn{2}{|c|}{ Availability Data } & \multicolumn{2}{|c|}{$\begin{array}{c}\text { Suitability } \\
\text { Data }\end{array}$} & \multirow[t]{2}{*}{ Penjelasan } \\
\hline & $\begin{array}{l}\text { Avai- } \\
\text { lable }\end{array}$ & $\begin{array}{l}\text { Not } \\
\text { Avai- } \\
\text { lable }\end{array}$ & $\begin{array}{c}\text { Suita- } \\
\text { ble }\end{array}$ & $\begin{array}{c}\text { Not } \\
\text { Sui- } \\
\text { table }\end{array}$ & \\
\hline 1 & & & & & $\begin{array}{l}\text { Hazard and } \\
\text { disaster data is not } \\
\text { available, analysis } \\
\text { and substance are } \\
\text { not based on DRR } \\
\text { concept }\end{array}$ \\
\hline 2 & & & & & $\begin{array}{l}\text { Data available, } \\
\text { analysis and } \\
\text { substance based } \\
\text { on DRR concept, } \\
\text { but quality must } \\
\text { be improved }\end{array}$ \\
\hline 3 & & & & & $\begin{array}{l}\text { Data available, } \\
\text { analysis and } \\
\text { substance based } \\
\text { on DRR concept } \\
\text { and good quality }\end{array}$ \\
\hline 4 & & & & & $\begin{array}{l}\text { Data available, } \\
\text { analysis and } \\
\text { substance based } \\
\text { on DRR Concept, } \\
\text { good quality, and } \\
\text { detail explanation }\end{array}$ \\
\hline
\end{tabular}

\section{Results and Discussions}

The following is score classification of Regional Regulation No. 17 Year 2012 on Spatial Plan of Karangasem Regency (Table 2).

Assessment of Regional Regulation No. 17 Year 2012 on Spatial Plan of Karangasem Regency represent that spatial plan does not have a score of 4 as the highest score in each of substance. The highest score is 3 which is found goal, policies, and strategies substance. The majority score of spatial plan is 1 and 2 . The result indicates that data, analysis, and substance need more improve about DRR concept. It can be concluded that the quality of spatial planning in Karangasem regency is sufficient.

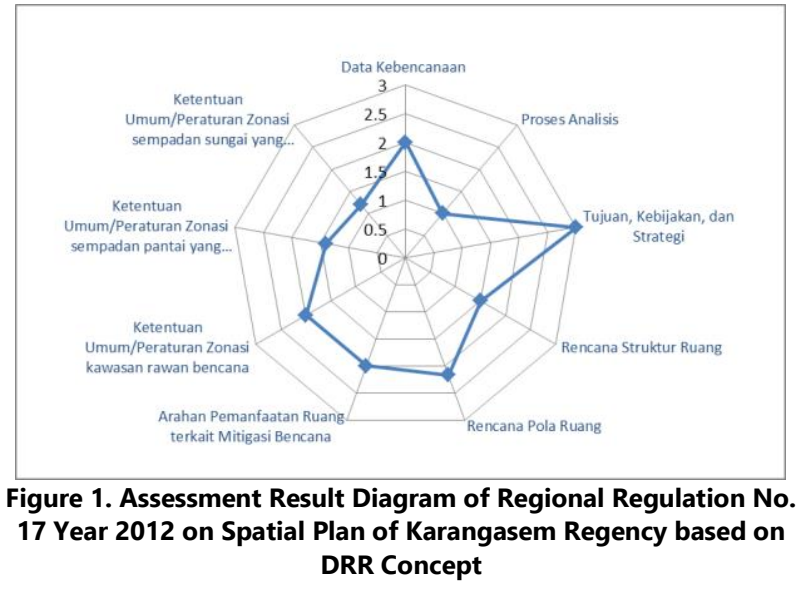


Table 2. Assessment Result of Regional Regulation No. 17 Year 2012 on Spatial Plan of Karangasem Regency

\begin{tabular}{|c|c|c|c|c|c|c|}
\hline \multirow[b]{2}{*}{$\begin{array}{l}\text { Spatial Planning } \\
\text { Substance }\end{array}$} & \multirow[b]{2}{*}{ Disaster Aspect } & \multicolumn{2}{|c|}{ Availability Data } & \multicolumn{2}{|c|}{ Suitability Data } & \multirow[t]{2}{*}{ Score } \\
\hline & & Available & $\begin{array}{c}\text { Not } \\
\text { Available }\end{array}$ & Suitable & $\begin{array}{c}\text { Not } \\
\text { Suitable }\end{array}$ & \\
\hline \multirow[t]{3}{*}{ Hazard Data and Map } & Map Type & & & & & 2 \\
\hline & Source & & & & & 2 \\
\hline & Scale & & & & & 2 \\
\hline \multirow[t]{3}{*}{ Analysis Process } & Disaster Risk Analysis & & & & & 1 \\
\hline & Mitigation Analysis & & & & & 1 \\
\hline & Land capability and Suitability Analysis & & & & & 1 \\
\hline \multirow{3}{*}{$\begin{array}{l}\text { Goal, Policies, and } \\
\text { Strategies }\end{array}$} & Goal & & & & & 3 \\
\hline & Policies & & & & & 3 \\
\hline & Strategies & & & & & 3 \\
\hline \multirow[t]{4}{*}{ Spatial Structure Plan } & Settlement Hierarchy System & & & & & 1 \\
\hline & Mitigation Infrastructure & & & & & 2 \\
\hline & Evacuation Route & & & & & 2 \\
\hline & Evacuation Space & & & & & 1 \\
\hline \multirow[t]{7}{*}{ Spatial Pattern Plan } & $\begin{array}{l}\text { Part of disaster prone area designated as a protected } \\
\text { area: }\end{array}$ & & & & & \\
\hline & $\begin{array}{l}\text { - The high volcano ashes and pyroclastic clouds } \\
\text { disaster prone area }\end{array}$ & & & & & 2 \\
\hline & - Land slide disaster prone area & & & & & 2 \\
\hline & - $\quad$ Active fault & & & & & 2 \\
\hline & $\begin{array}{l}\text { - Tsunami disaster prone area (beach border that } \\
\text { considers tsunami) disaster prone }\end{array}$ & & & & & 2 \\
\hline & - $\quad$ Flood (river border that considers flood) & & & & & 2 \\
\hline & Strategic Area & & & & & 3 \\
\hline $\begin{array}{l}\text { Direction of spatial } \\
\text { utilization consider }\end{array}$ & Mitigation infrastructure program & & & & & 2 \\
\hline mitigation & Mitigation non-infrastructure program & & & & & 2 \\
\hline \multirow{5}{*}{$\begin{array}{l}\text { Zoning Regulation of } \\
\text { Disaster Prone Area }\end{array}$} & Types of not allowed activities & & & & & 2 \\
\hline & Requirements of space utilization intensity & & & & & 2 \\
\hline & Requirements of building construction and engineering & & & & & 2 \\
\hline & Minimum facilities and infrastructure & & & & & 2 \\
\hline & Vegetation & & & & & 2 \\
\hline Zoning Regulation of & Types of not allowed activities & & & & & 2 \\
\hline $\begin{array}{l}\text { Beach Border that } \\
\text { considers Tsunami }\end{array}$ & Requirements of space utilization intensity & & & & & 1 \\
\hline \multirow[t]{3}{*}{ Disaster Prone } & Requirements of building construction and engineering & & & & & 1 \\
\hline & Minimum facilities and infrastructure & & & & & 1 \\
\hline & Vegetation & & & & & 2 \\
\hline
\end{tabular}




\begin{tabular}{|c|c|c|c|c|c|c|}
\hline \multirow[b]{2}{*}{$\begin{array}{l}\text { Spatial Planning } \\
\text { Substance }\end{array}$} & \multirow[b]{2}{*}{ Disaster Aspect } & \multicolumn{2}{|c|}{ Availability Data } & \multicolumn{2}{|c|}{ Suitability Data } & \multirow[t]{2}{*}{ Score } \\
\hline & & Available & $\begin{array}{c}\text { Not } \\
\text { Available }\end{array}$ & Suitable & $\begin{array}{c}\text { Not } \\
\text { Suitable }\end{array}$ & \\
\hline \multirow{5}{*}{$\begin{array}{l}\text { Zoning Regulation of } \\
\text { River Border that } \\
\text { considers Flood } \\
\text { Disaster Prone }\end{array}$} & Types of not allowed activities & & & & & 2 \\
\hline & Requirements of space utilization intensity & & & & & 1 \\
\hline & Requirements of building construction and engineering & & & & & 1 \\
\hline & Minimum facilities and infrastructure & & & & & 1 \\
\hline & Vegetation & & & & & 1 \\
\hline
\end{tabular}

\section{Conclusion}

The following is research conclusion:

- Spatial plan of Karangasem Regency should be using updated and valid hazard data and map

- Spatial Plan of Karangasem Regency consider hazard prone and risk analysis

- Developing of mitigation infrastructure and noninfrastructure

- Restriction of built-up area in disaster prone area

\section{References}

Central Statistics Agency. (2019). Indikator Isu Strategis. Bali: BPS Geologycal Agency. (2011). Katalog Data Dasar Gunungapi. Jakarta: Kemen. ESDM

Reyes, Marqueza L. (2004). Risk-Sensitive Land Use Planning: Towards Reduced Seismic Disaster Vulnerability (The Case of Marikina City, Metro Manila, Philippines). Jerman: Kassel University

Suryana, Dayat. (2012). Karakteristik Provinsi di Indonesia. Bandung: CreateSpace Independent Publishing Platform

Sutanta, Heri. (2012). Spatial Planning Support System for an Integrated Approach to Disaster Risk Reduction. Australia: Department of Infrastructure Engineering, School of Engineering, The University of Melbourne 